\title{
CLASSIFYING THE MEDITERRANEAN TERRACED LANDSCAPE: THE CASE OF ADRIATIC CROATIA
}

Goran Andlar, Filip Šrajer, Anita Trojanović

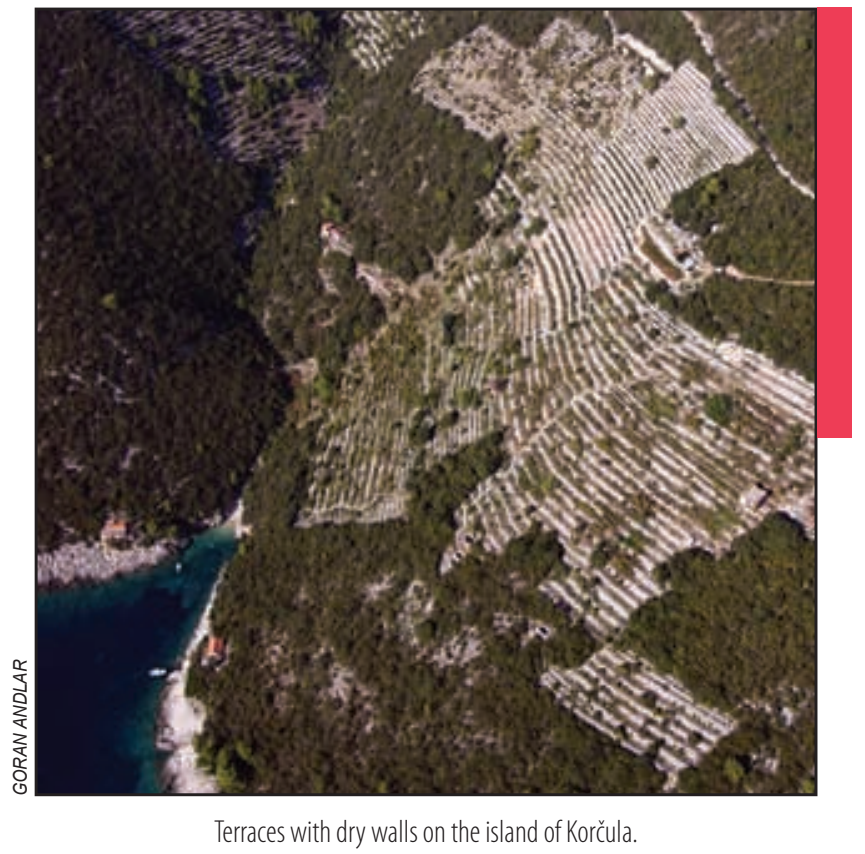




\section{Classifying the Mediterranean terraced landscape: The case of Adriatic Croatia}

DOI: http://dx.doi.org/10.3986/AGS.4673

UDC: $911.53: 631.613(497.57)$

COBISS: 1.01

ABSTRACT: This article presents a Croatian Adriatic terraced landscape classification, highlighting its natural and cultural background and proposing a classification framework for further research. The classification is based on the landscape level (i.e., the »landscape pattern level«), synthesizing its structural, biophysical, and cultural-historical dimensions. The interpretation of classes involves a combination of general land use, structure, geomorphology, local land use, crops, soil type, and historical aspects. Nine classes of terraced landscapes are identified and described, example locations are given, and they are substantiated with illustrations and photos.

KEYWORDS: landscape classification, cultural landscape, terraces, agricultural land use, Mediterranean, Adriatic, Croatia

The article was submitted for publication on September $9^{\text {th }}, 2016$.

\section{ADDRESSES:}

Goran Andlar, Ph.D.

Department of Ornamental Plants, Landscape Architecture, and Garden Art

Faculty of Agriculture, University of Zagreb

Svetošimunska cesta 25, HR-10000 Zagreb, Croatia

E-mail: gandlar@agr.hr

Filip Šrajer, M.Sc.

Urbing d.o.o.

Avenija V. Holjevca 20, HR-10000 Zagreb, Croatia

E-mail: filip.srajer@gmail.com

\section{Anita Trojanović}

Pavlje Brdo 3, HR-20215 Gruda, Croatia

E-mail: anita.trojanovic@gmail.com 


\section{Introduction}

Agriculture terracing involves leveling slopes in order to create accessible, flat, or sloped plots for agricultural, silvicultural, or pastoral use. The terraces allow the redistribution of soil and prevent soil erosion by controlling the quantity of existing soil and soil brought from the surroundings by man or controlled erosion (Countryman 2012). Terracing has many positive effects because it makes it possible for roots to penetrate hard ground and provides control of the water regime. It also contributes to protecting the ground from wind and ensures better insolation. The shape of terraces depends on various factors, such as their purpose, soil properties, lithology, and relief characteristics, and on construction craftsmanship and local agricultural practices.

Cultivated terraces are a prominent feature of the Mediterranean agricultural landscape, and due to their cultural, ecological, and aesthetic value they have had great importance for a range of academic disciplines (Titl 1965; Price and Nixon 2005; Asins-Velis 2006; Acovitsióti-Hameau 2008; Kale 2011; Sluis, Kizos and Pedroli 2014; Gadot et al. 2016). On the other hand, contribution by Croatian researchers and information on Croatia's terraced landscapes are scant and do not correspond to the variety of efforts invested in their protection (Gotthardi Pavlovsky 1972; Kladnik, Šmid Hribar and Geršič 2017) and interpretation (Gams 1987). These circumstances and the fact that rural exodus, tourism, and new agricultural techniques are increasingly endangering the integrity of terraced and other cultural landscapes (Andlar and Aničić 2017) necessitated an extensive study (Andlar 2012) to assess and evaluate Croatia's Adriatic cultural landscapes. The research showed the great diversity of agricultural terraced landscapes in the region and provided sufficient data to establish a classification of terraced landscapes and a framework for future research.

\subsection{Natural and cultural-historical background}

The Croatian Adriatic region extends across approximately one-third of Croatian territory $\left(18,000 \mathrm{~km}^{2}\right)$. This predominantly karst area is characterized by a Mediterranean climate, high complexity of relief forms, thin soil, sparse natural vegetation, lack of surface water (Filipčić 1998; Bognar 2001; Andlar 2012), and a EuroMediterranean cultural context. High and irregularly distributed precipitation, along with high soil erosivity, have resulted in high ecological sensitivity of the area (Cvijić 1918; McNeil 2003; Grove and Rackham 2001). Natural conditions are harsh but vary significantly due to the great diversity of environmental factors (Ciglič et al. 2012), which has led to a high diversity of human adaptation, in which terracing has played an important role in stabilizing resources on steep slopes and in valleys, dolines, and gullies (Andlar 2012).

The diversity of terraces can be observed from the cultural point of view. Many areas have a distinctive pattern of terraces that reflects cultural and economic influences, and local practices. Due to the high endurance of stone and slow modernization processes, agricultural landscapes still testify to the earliest times of human culture. Terracing has probably been present since the first agricultural activity in steep terrain. However, there is no clear evidence of the evolution of terracing techniques over time; it may have remained unchanged for thousands of years. Many researchers believe that terracing was already present in the Mediterranean in the Neolithic (Price and Nixon 2005; Hughes 2005), whereas other research shows that the first terraces were built during the Bronze Age (Countryman 2012; Grove and Rackham 2001). This was probably related to the spread of agriculture practices and the establishment of a Mediterranean polyculture with the introduction of new agricultural techniques, including terracing. In Croatia, some stone structures have been found in Neolithic settlements (Moore et al. 2007) and on the site of an Iron Age hill fort (Barbarić 2010) (it is rather certain that the terracing happened in the nineteenth or twentieth century), but no clearly prehistoric terraces could be confirmed. In the Greek and Roman period, terracing was clearly present in newly farmed land. For example, the ancient Greek geometrical system of land division has been preserved on the Stari Grad plain on the island of Hvar (Zaninović 2002), and it influenced the spatial organization of terraced fields.

The next indicative period was the High Middle Ages to Early Modern Age. The Euro-Mediterranean area had flourishing agricultural production from the eleventh to thirteenth century due to the agrarian revolution and economic development (Delort and Walter 2002). In the eastern Adriatic, the development of agricultural communities was fostered by the establishment of medieval statutes, which, in some cases, regulated how agricultural land and terraces were managed (e.g., the Dubrovnik Statute of 1272). From the early fifteenth century onward, some eastern Adriatic islands were targets of regional immigration after 
the Ottoman annexation of the Adriatic hinterland (sixteenth to eighteenth centuries), and the additional need for arable land was met by allocations (Latin gratia; Kasandrić 1978) of former communal land (mostly pastures) to the new settlers for cultivation (Carter 1992; Kovačić 1993; Tudor 2004; Dokoza 2009). Evidence of early terraced landscapes can be seen in a 1573 bird's eye view of the island of Korčula prepared by Simon Pinargenti (Marković 2001). The southern coastal slopes of Dingač on the Pelješac Peninsula were also cleared for growing grapes in the sixteenth century (Glavina 2008).

The last large-scale karst reclamation with extensive terrace construction took place in the late nineteenth and early twentieth centuries, and was caused by large-scale environmental and socio-political events such as the pandemics of grapevine diseases that first hit the leading winegrowing regions of France and Italy, the ease of international sale through established Austro-Hungarian trade links and the empire's large market, and the partial transfer of land ownership (or at least disposal rights) from large landlords, the state, or communes to the wider population (Trogrlić 1980; Kale 2006 and 2010; Kraljević 1994; Kulušić 2006; Žuvela-Doda 2008). This period of growth ended in a similar way: suddenly and as a result of larger events such as the First World War, the 1918 flu pandemic, and several others that led to a large-scale crisis that resulted in land abandonment and exodus (Kraljević 1994). Because the vast majority of extremely steep slopes, remote areas, and uninhabited islets have never been reclaimed again, it can be argued that laborintensive terrace construction and maintenance were only possible under extraordinary socioeconomic conditions. Therefore, these large-scale landscape transformations were far from sustainable, as opposed to polyculture, which is common in the Mediterranean.

The most notable example of terrace construction soon after the Second World War is the creation of the terraced vineyards in the Primošten area, carried out in the first period of communist collectivization, when agricultural cooperatives were established (Kale 2006), similar to eastern Slovenia (Kladnik et al. 2016b; Pipan and Kokalj 2017). The vineyards were newly planned and designed, but they were inspired by landscape patterns from the surrounding area. This method proved to be successful and could be recommended for planning karst land reclamation in the future.

\subsection{Classification of terraces}

It can be observed that there is lack of standardized nomenclature and classification of terraces. For example, a constructive typology of terraces was given in the transnational project ALPTER (Internet 1) but its nomenclature was primarily based on Italian terms, such as balk (Italian ciglioni), fanlight (Italian lunette), step (Italian gradoni), terrace, and terrace construction (Scaramellini 2008). The terrace typology most often cited is probably that by Grove and Rackham (2001), who classified Mediterranean terraces based on their construction and structural characteristics: step terraces, pocket terraces, braided terraces, check-dam terraces, and terraced fields.

A terrace consists of three parts. The terrace wall is referred to as a riser, the flat planting surface is the tread or platform, and the soil in the interior of the terrace behind the riser is the fill (Countryman 2012; cf. Frederick and Krahtopoulou 2000, 80). The direction of the riser is usually parallel to the terrain contours.

Based on the type of riser, the following basic terrace types were distinguished in the research area:

- Terraces with built risers; a dry stone wall supporting the construction is the most common, and the riser is vertical, or gently sloped towards the terraced plot. Other forms of supporting structures are possible but are very rare, such as wattle.

- Terraces with a vegetation riser; hedges or trees are intentionally or spontaneously grown.

- Unwalled terraces; these are shaped intentionally or spontaneously due to ploughing longitudinally along the contour lines. This type of terrace is particularly associated with heavy textured soils.

\section{Methods}

The terraced landscapes in the Croatian Adriatic region have not yet been the subject of systematic investigation. General or site-specific interpretations of Croatian Adriatic karst land use, and terraced or dry stone landscapes from the archaeological, geographical, architectural, structural, biophysical, ethnological, or historical points of view are given by Aničić and Perica (2003), Borovičkić (2008), Buble (2009), Freudenreich (1962), Gams (1991), Kale (2006, 2008, 2010), Kulušić (1999, 2006), Lozić et al. (2013), Petrić (2008), 
Slapšak et al. (1998), Tudor (2004), Zaninović (2002), and Zupančič (2010). In neighboring Slovenia, the research project Terraced Landscapes in Slovenia as Cultural Values (2011-2015) produced a systematic inventory of terraces throughout the entire country. Characterization of terraces was carried out within Slovenian landscape types and based on construction techniques, purpose, metrics, biophysical features, and the history of terracing (Ažman Momirski and Kladnik 2008; Kladnik et al. 2016a; Šmid Hribar et al. 2017).

The first comprehensive study of the Croatian Adriatic cultural landscape was based on extensive research on land use and identity in agricultural, forestry, and salt-extraction landscapes. In order to identify outstanding cultural landscapes, landscape history and classification studies were carried out (Andlar 2012; Andlar and Aničić 2017):

- Research on rural landscape history provided a chronological outline of successive historical periods with common social and spatial patterns. Its purpose was to outline the history and identity of the present landscape and to understand the historical background on a regional level and at the particular locations observed .

- Landscape classification was based on the model of functional, structural, and cultural-historical aspects of landscape types, synthesizing several theoretical and practical approaches (e.g., Fairclough 2010). The classification consists of three levels: the first one is based on general land-use categories, the second revolves around the concept of land-use structure, and the third applies the concept of structural, functional, and cultural-historical landscape character.

These historical and classification studies, along with descriptions of outstanding landscapes (half of the sixty-three sites identified are terraced or partially terraced), were used in this article as a starting point for terraced landscape analysis and classification. Additional information was collected through a series of local landscape character assessments and a WebGIS public participatory database of Croatian Adriatic dry stone wall heritage (Suhozid ... 2016). Creation of the register involved combined flyovers and fieldwork carried out since 2007, establishment of a geo-tagged photo register, and analysis of data from various available sources, such as historical and recent digital orthophoto images, topographic, soil, and historical maps, and CORINE land cover (CORINE ... 2016), Google Earth (Google Earth 2016), and ARKOD data (ARKOD 2016).

\section{Classification of terraced landscapes}

The classification was based on the "landscape pattern scale, « which is defined as consecutive repetition of a similar anthropogenic structure in relation to particular natural and cultural features (Andlar and Aničić 2017). Identification of the terraced landscape class was based on a synthesis of structural, natural, and anthropogenic factors; namely, general land use, structure and geomorphology, local land use, crops and soil type, and historical aspects. Each class is presented with a sketch and an example location is given.

\subsection{Terraced field landscapes}

The following terraced landscape types are part of »field landscapes, « which are defined by the presence of natural cultivated soil, where cultivation is primarily achieved through ploughing. It is related to karst depressions with undulating bottoms that have been cultivated with shallow, non-consecutive, and wide terraced fields. The main types of such landscapes are the following:

(A) Wide regular-pattern terraced fields in landscapes with karst poljes and river valleys (Figure 1) are associated with large karst depressions with shallow terracing with mildly undulating bottoms. Due to their spaciousness and gentle slopes, regular (sometimes planned) patterns are common. The terraces are usually combined with fields and enclosures, forming a mixed crop system defined by the proximity of settlements and a complex history, such as Stari Grad on the island of Hvar.

(B) Wide irregular-pattern terraced fields in landscapes with karst uvalas and large dolines (Figure 1) are associated with moderate-sized karst depressions with pronounced relief and consequently irregular and organic terrace patterns. This type involves various land uses with mixed crops, and is related to small nucleated or scattered settlements and hamlets located above the field. This is a typical rural land pattern in the Adriatic hinterland. 


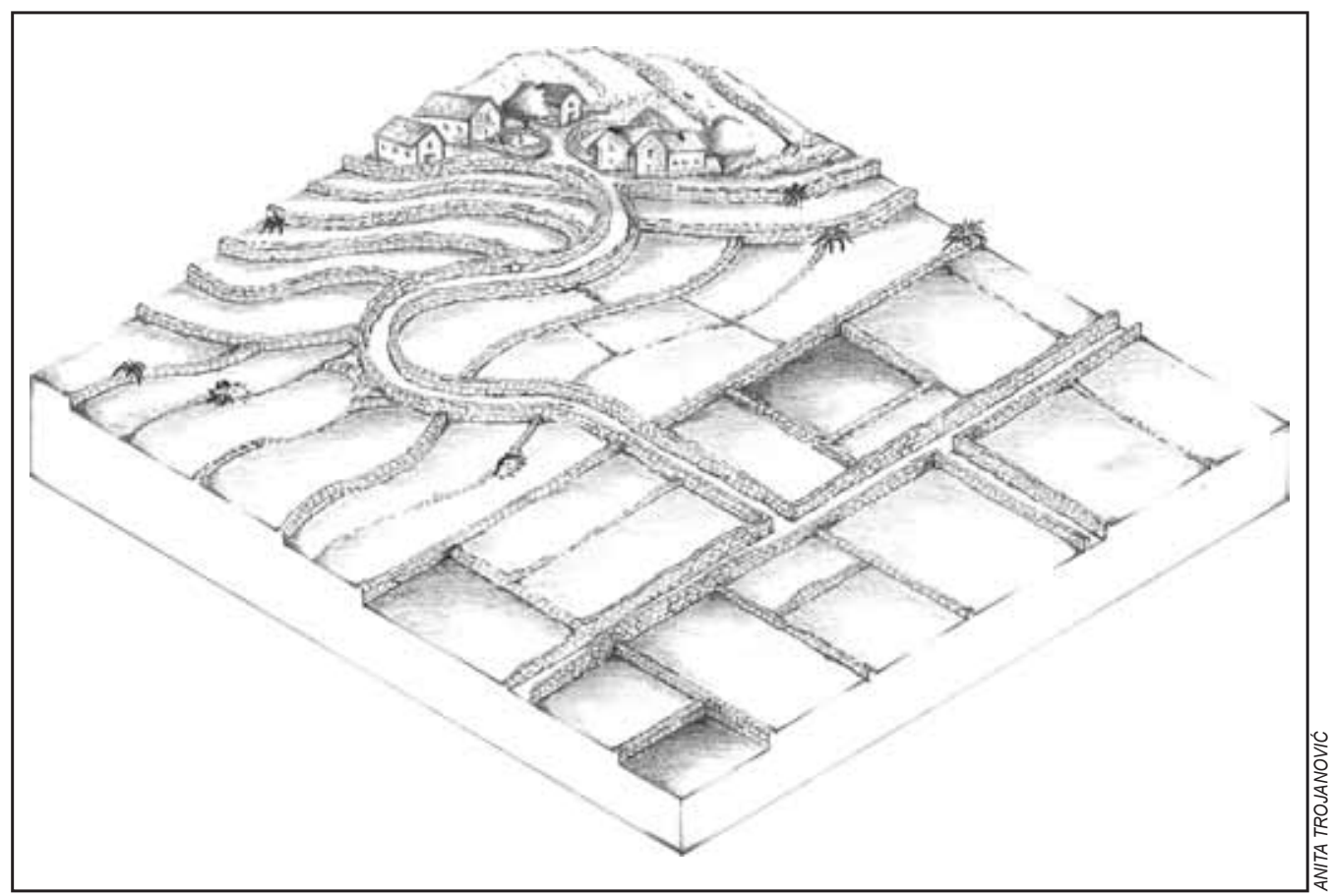

Figure 1: Irregular- and regular-pattern terraced fields (left to right)

(C) Terraced fields in landscapes with shallow ravines and dry valleys (Figure 2). Sloping, narrow, elongated dry valleys and ravines create oases with arable soil that were enclosed by dry walls and terraced in order to preserve soil and control water flow during thunderstorms. Interesting examples can be found on the island of Brač, where narrow, winding valleys up to ten kilometers long with a single row of terraced fields with mixed or vineyard use can be observed. A variation of this class is seen on the island of Krk, where scattered terraced enclosures can be found in cultivated gullies.

(D) Terraces and terraced fields landscapes on colluvium (Figure 2). A particular type of terraces evolved on very steep colluvium (even exceeding $35^{\circ}$ ), where consecutive terracing is not common because of its physical characteristics and resistance to erosion. The inclination is unchanged or slightly flattened, and the risers are sporadic. Large, elongated deposit patches are completely cultivated and sometimes enclosed by dry stone walls. The fertile and porous soil is suitable for cultivating quality grape varieties. Such sites are located on southern coastal slopes of the island of Hvar and on the Pelješac Peninsula. The emergence of these terraces is likely to be associated with the first period of karst land reclamation.

(E) Unwalled terraced field landscapes (Figure 3). This type of terrace is associated with flysch areas such as »Gray« Istria (the flysch or clay central part of Istria) and the Ravni Kotari region, where built structures are not present (or are negligible) due to the lack of stone on the surface and the physical characteristics of the soil, whereas vegetation risers are common. It is characterized by a curved strip pattern. As opposed to neighboring karst areas, these areas have patches of fertile land, characteristic for mixed use with long continuity.

\subsection{Hillside terraced landscapes}

The following terraced landscape types are associated with consecutive terracing, dry stone wall risers, and narrow to moderate tread width, usually designed for one or several rows of cultivated plants (olives, grapes, lavender, etc.). Ploughing is absent or rare in these areas. Such terraced landscapes are common 


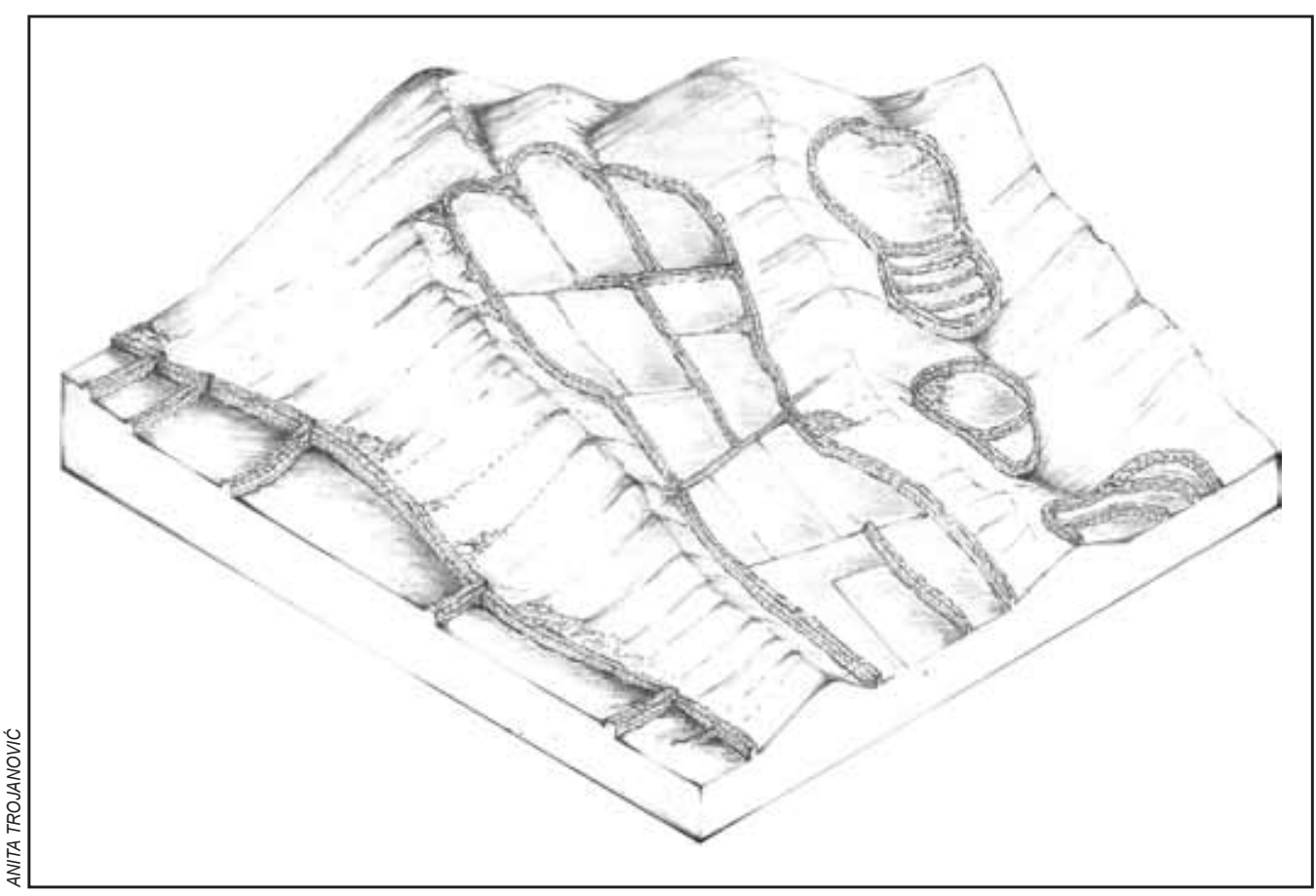

Figure 2: Terraced fields in a dry valley, terraces and terraced fields on colluvium, and a terraced shallow ravine (left to right).

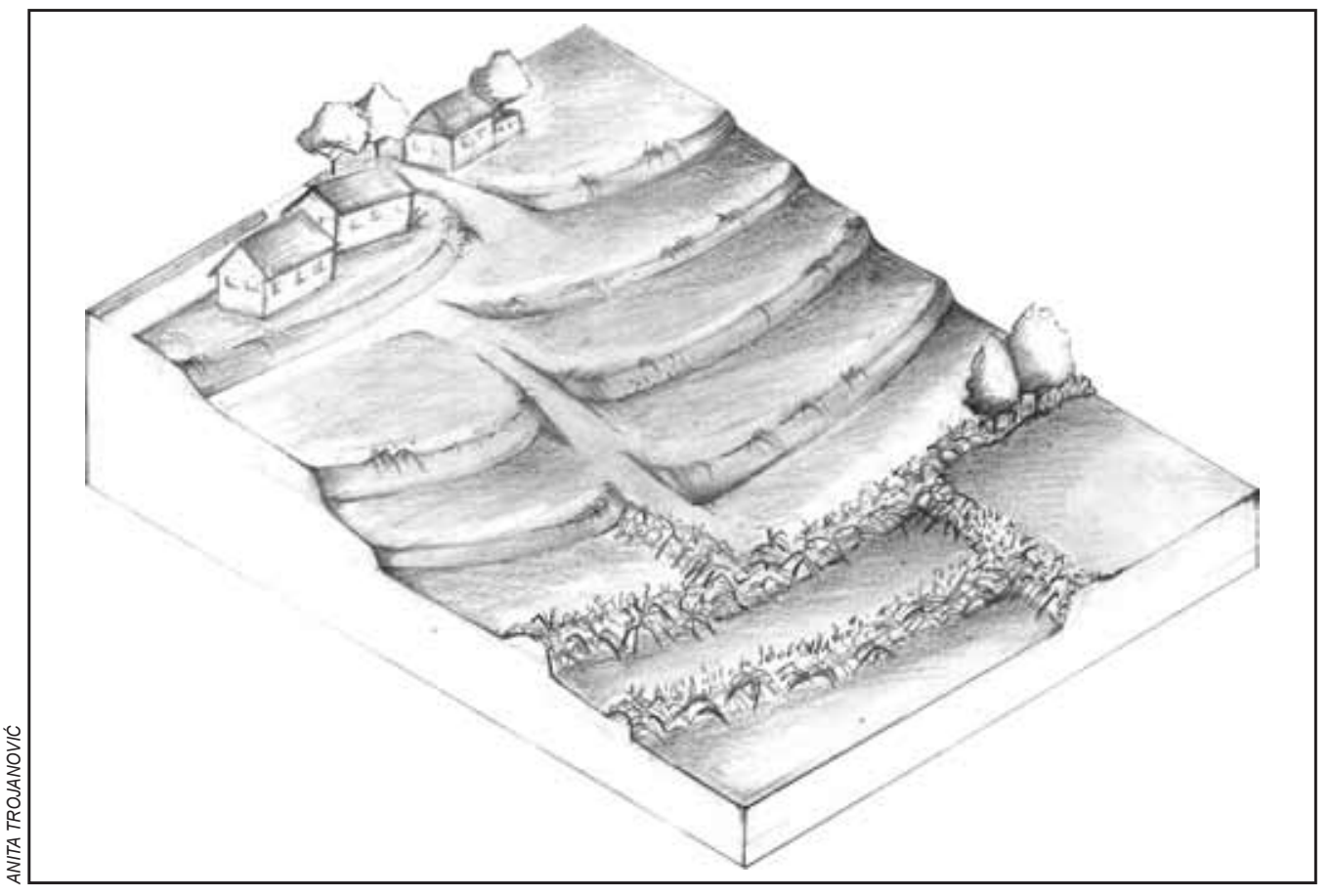

Figure 3: Unwalled terraced fields with and without vegetation risers. 
in remote, steep areas outside settlements and were initially intended to be monocultural due to karst land reclamation. The main types of hillside terraced landscapes are the following:

(F) Regular-pattern step-terraced landscapes (Figure 4). They are typical for the upper parts of slopes. The dry stone walls are usually solid and well built, and are sometimes higher than the tread width. The connection between terraces is achieved by steps cut into the riser, protruding from the riser, and/or on the top of piles of stone and walls that run along the slope. The terrace patterns are regular, but can vary, depending on various factors. Groups of terraces are sometimes enclosed by stone walls in various forms. Regular enclosures usually indicate later colonization, with the distribution of land organized among new owners. Very narrow terraces were initially mostly intended for growing grapes. This type can be found in the southern part of the islands of Korčula and Hvar, and in the hinterland of Trogir.

(G) Irregular-pattern terraced landscapes (Figure 5). This type is associated with an irregular plot pattern with a non-continuous riser, often containing a ramp that links the upper and lower treads. A poor-quality wall structure is common in this type, which can be found in areas with sparse surface stone or where rock fragments or small pebbles are found in soils. It is also typical for areas with sandy soils; for instance, on the island of Susak, where terrace risers are overgrown with reeds. Various crops may be associated to this type, but, unlike the previous one, grains, vegetables, and mixed use are more common.

(H) Pocket-pattern terraced landscapes. This type is associated with semicircular or triangular parcels, either laid out individually or in a series in a honeycomb pattern, which may contain a dry stone wall riser (Figure 6), but the riser may also be completely absent (or »spontaneous«; Figure 7). The latter subtype can be found on slopes with large stone fragments where natural voids in the rocks were slightly reshaped and filled with soil usually in order to grow individual plants (olives or grapes). Individual pocket terraces are intended to grow one cultivar, but larger pockets were probably used for creating small arable plots (e.g., for growing tansy or grains, or for meadows).

(I) Off-contour terraced landscapes (Figure 8). These atypical terraces are characterized by supporting walls laid out at an angle, sometimes even perpendicular to the terrain contours, characterized by a narrow pattern.

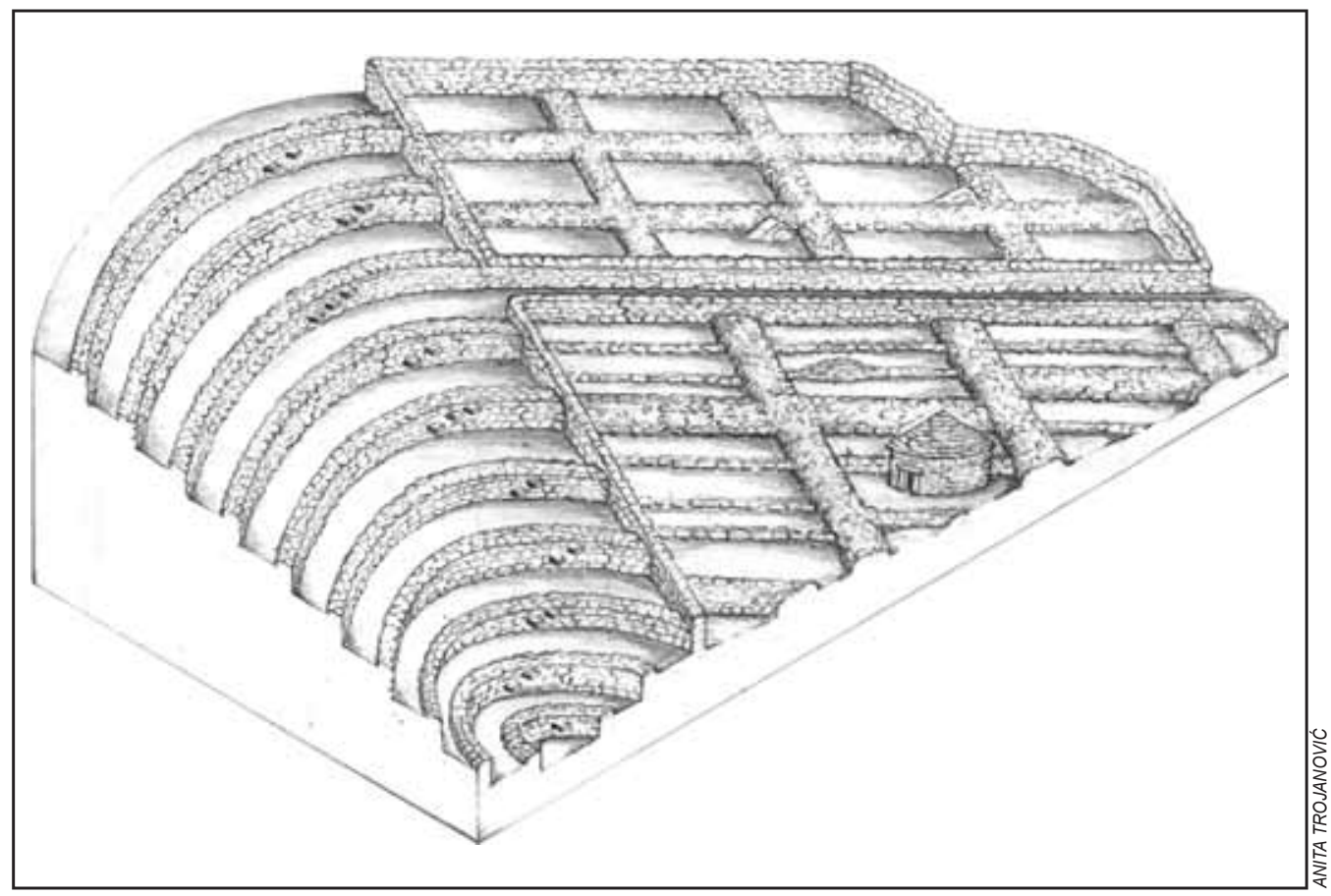

Figure 4: Variations of regular-pattern step terraces: a narrow organic pattern, a narrow vertically intersected pattern, and a wide rectangular pattern (left to right). 


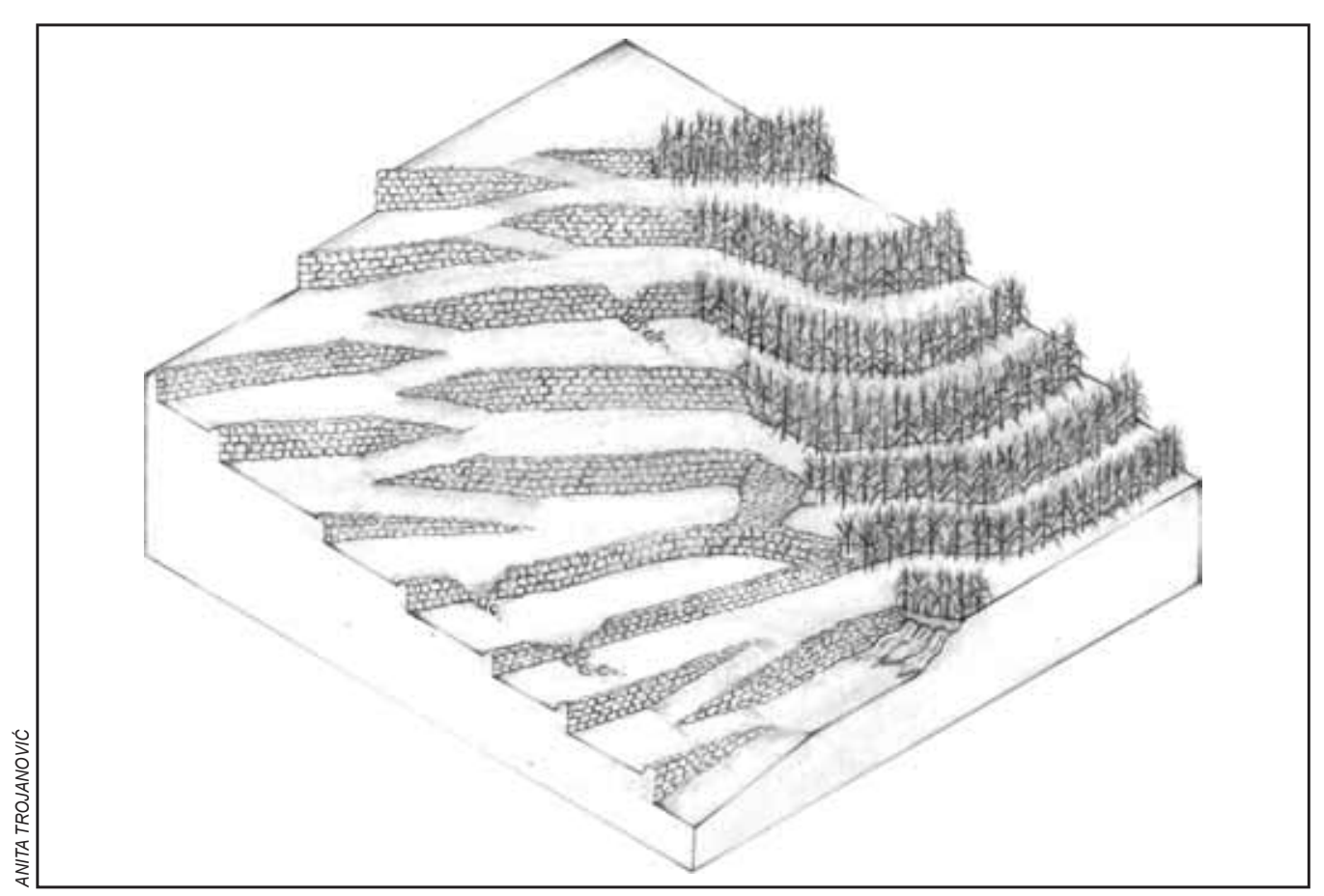

Figure 5: Irregular-pattern terraces with dry stone wall and vegetation risers (left to right).

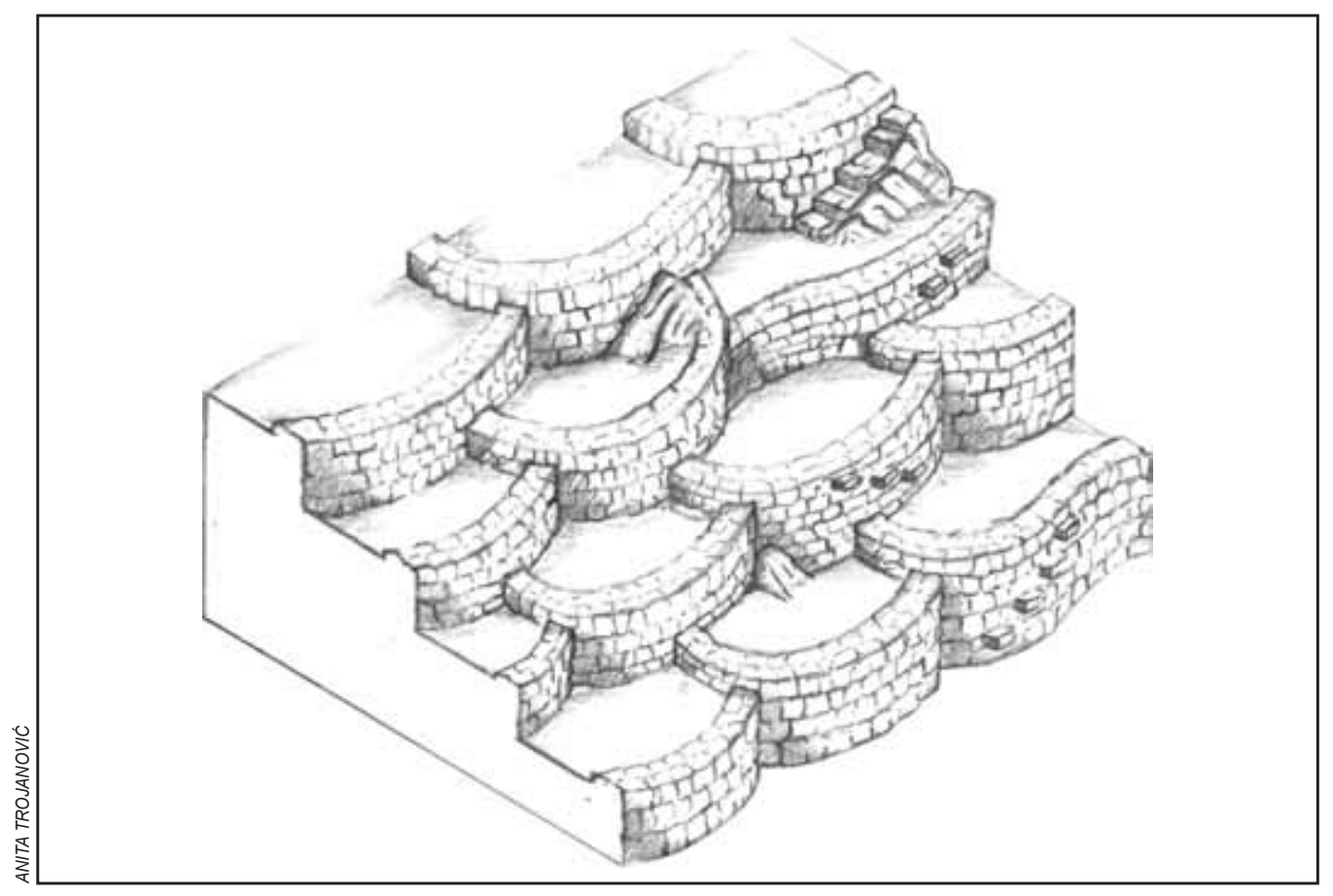

Figure 6: Pocket terraces. 


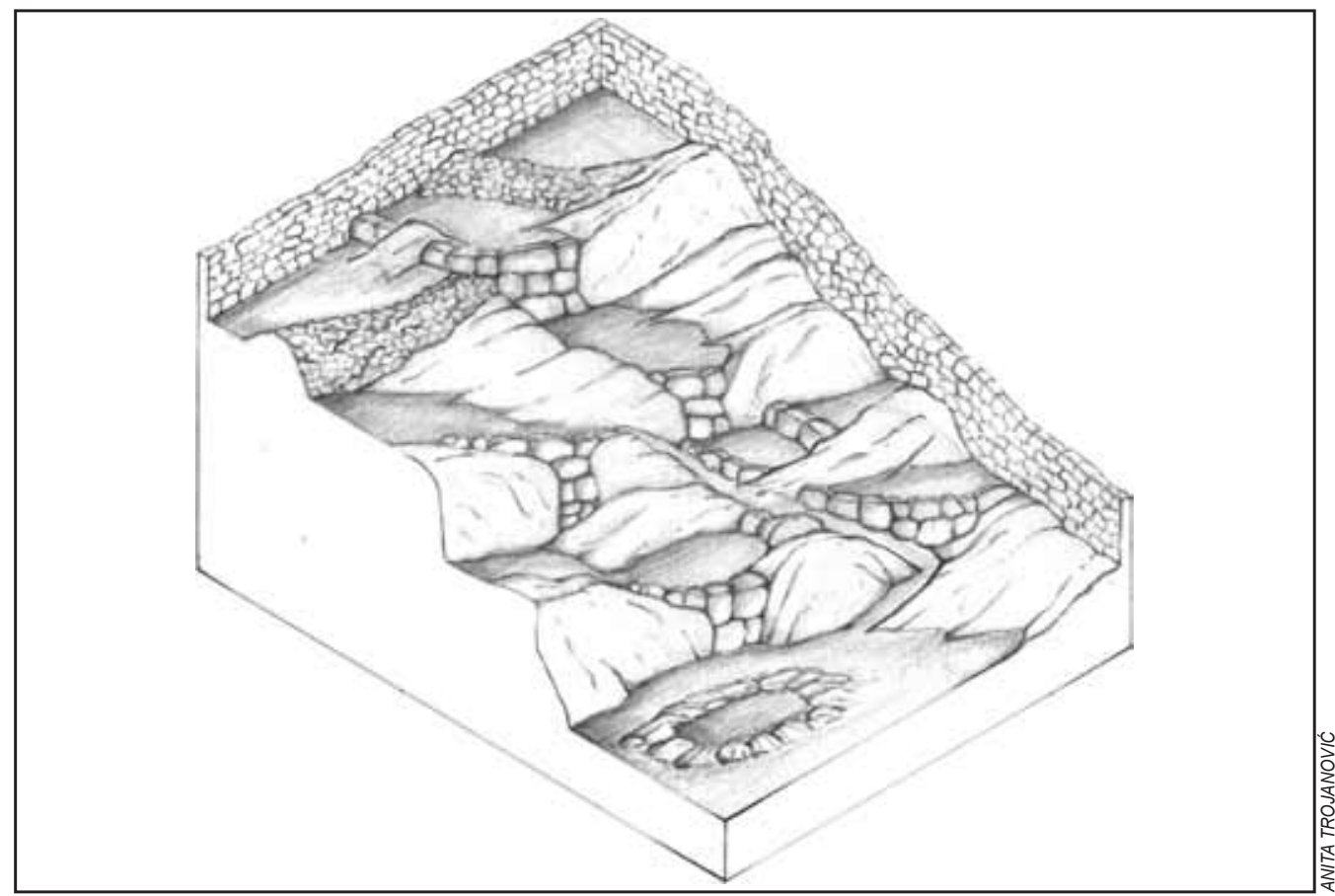

Figure 7: »Spontaneous« pocket terraces.

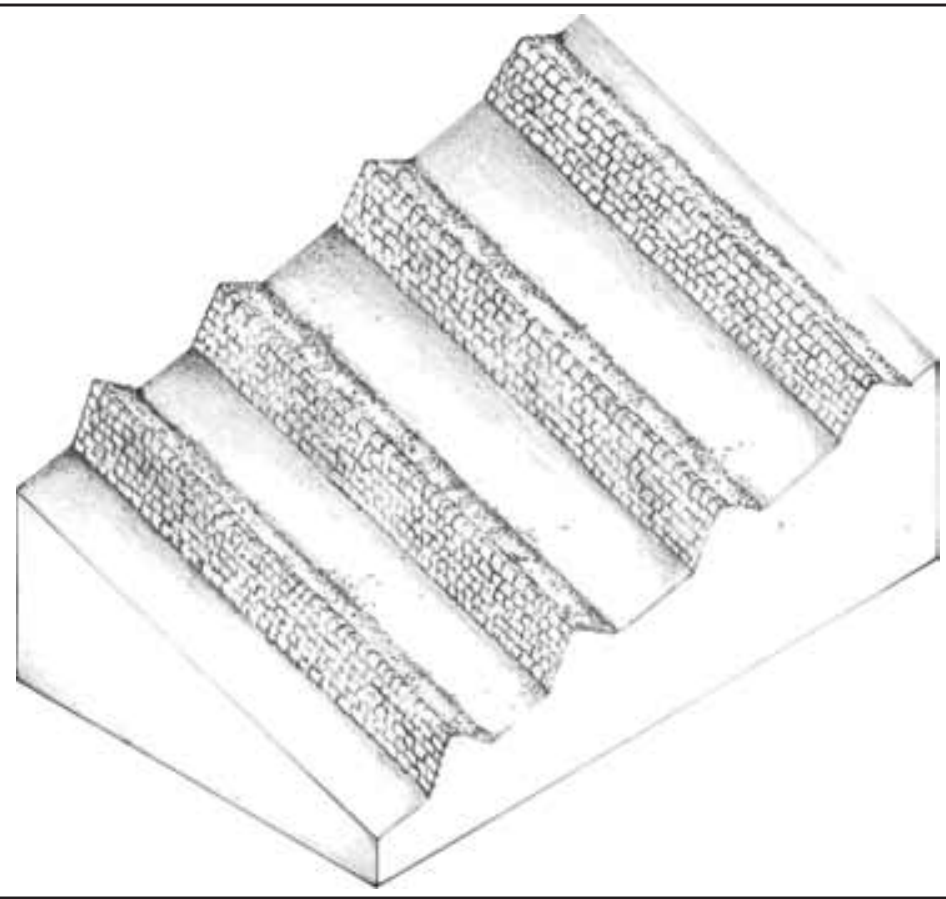

Figure 8: Off-contour terraces. 


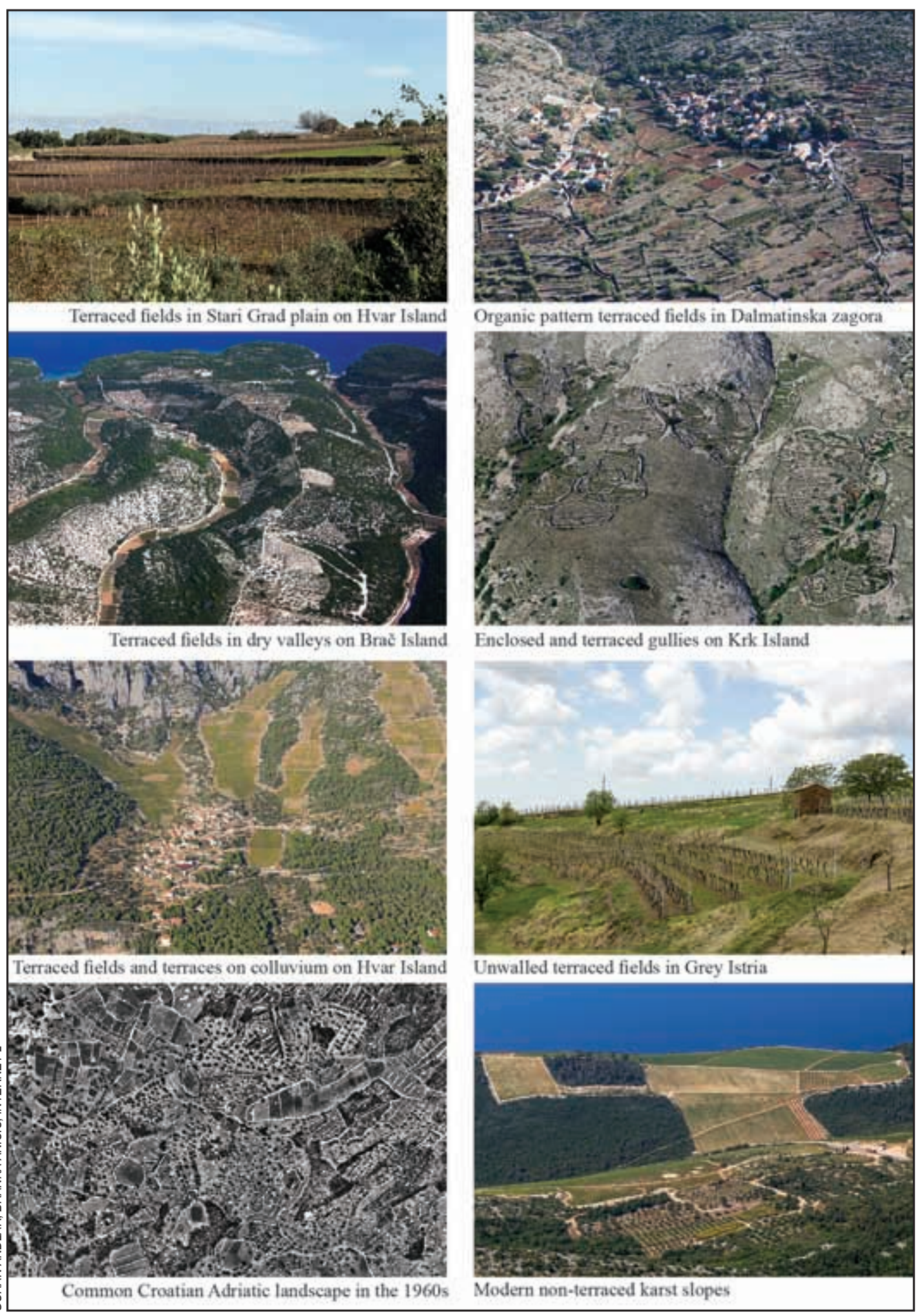

Figure 9: Photos of Croatian Adriatic terraced field landscapes; modern terraced and historical dry stone wall landscapes. 


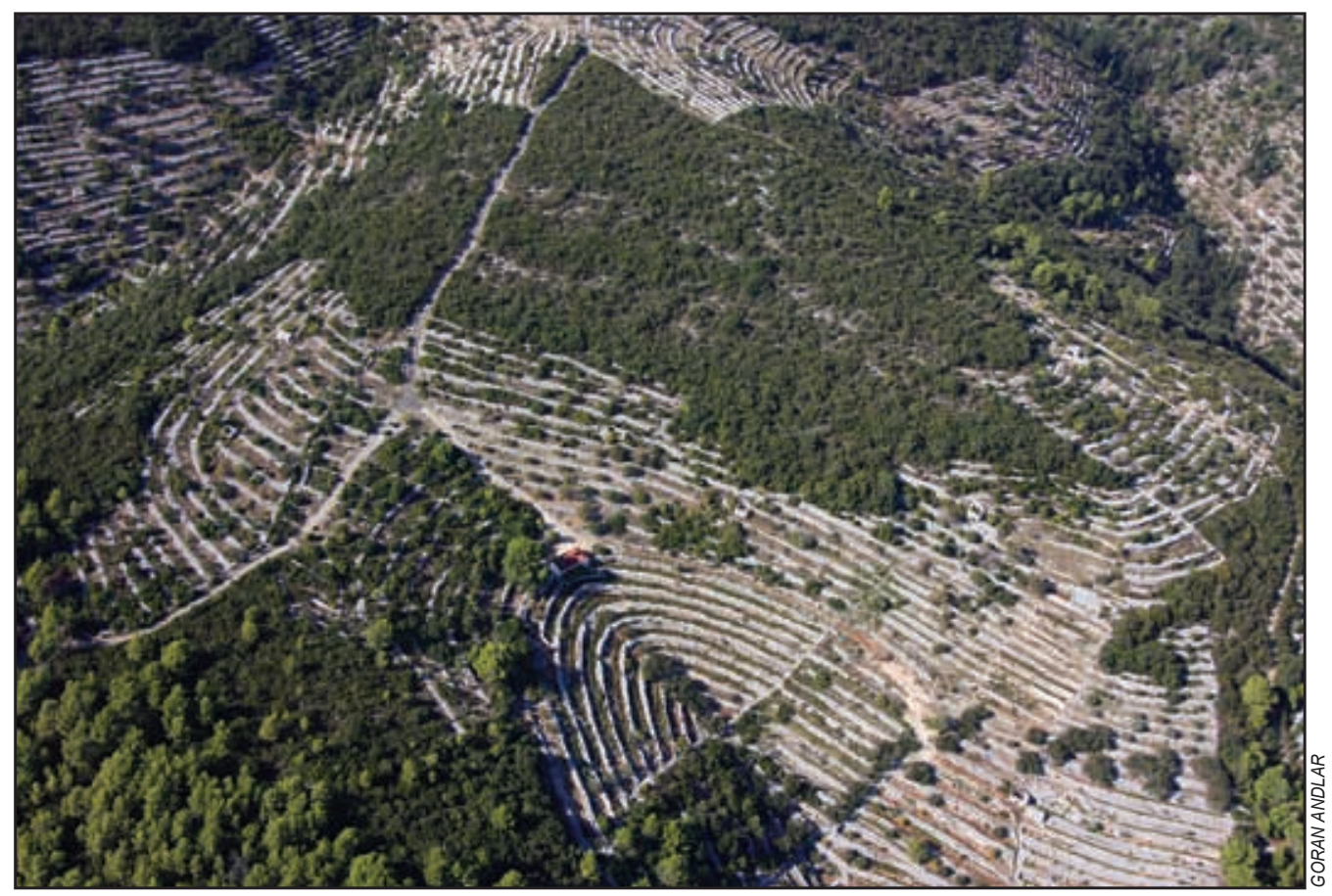

Figure 10: Korčula vineyards on narrow step terraces.

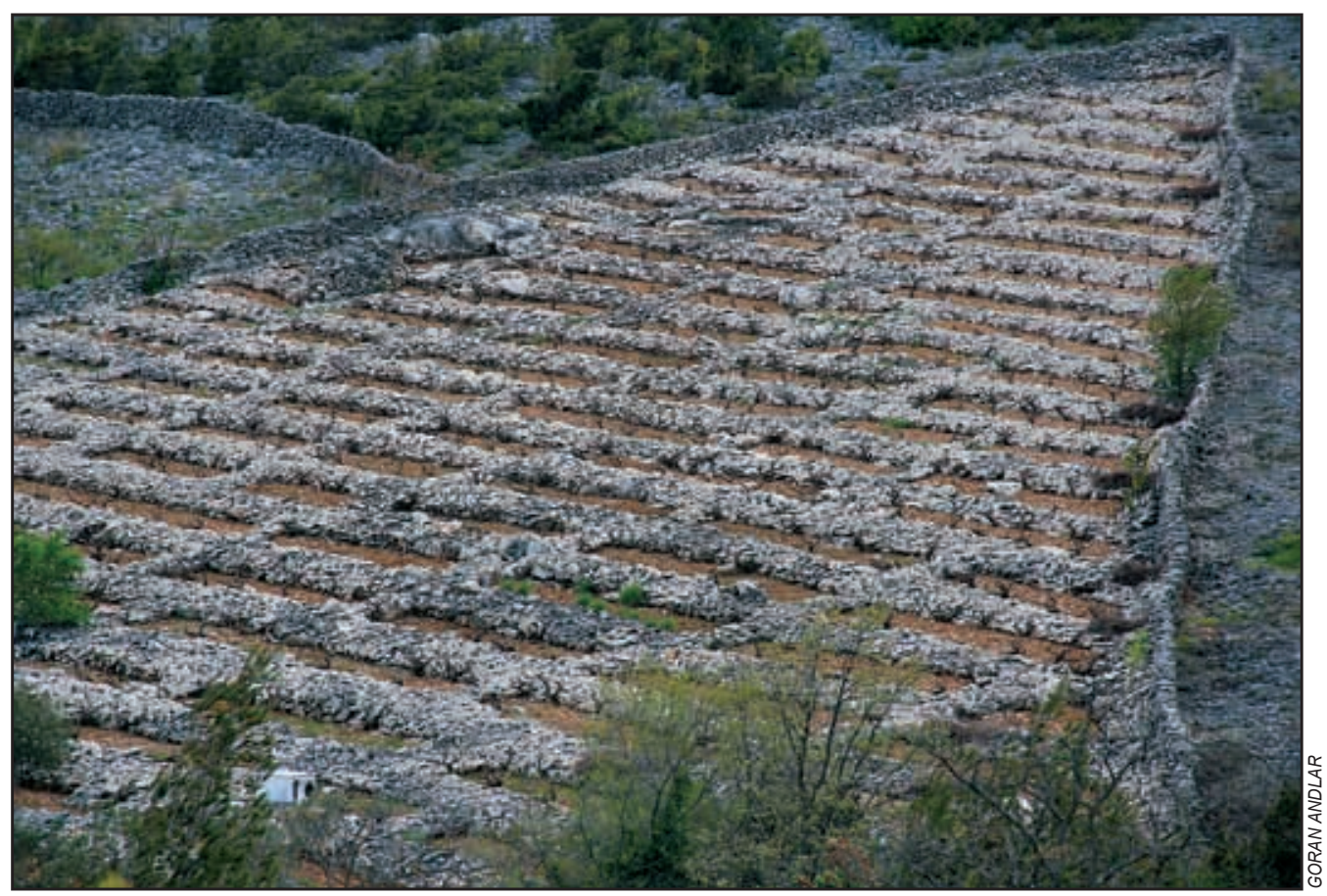

Figure 11: Short and wide vineyard terraces in the hinterland of Trogir. 


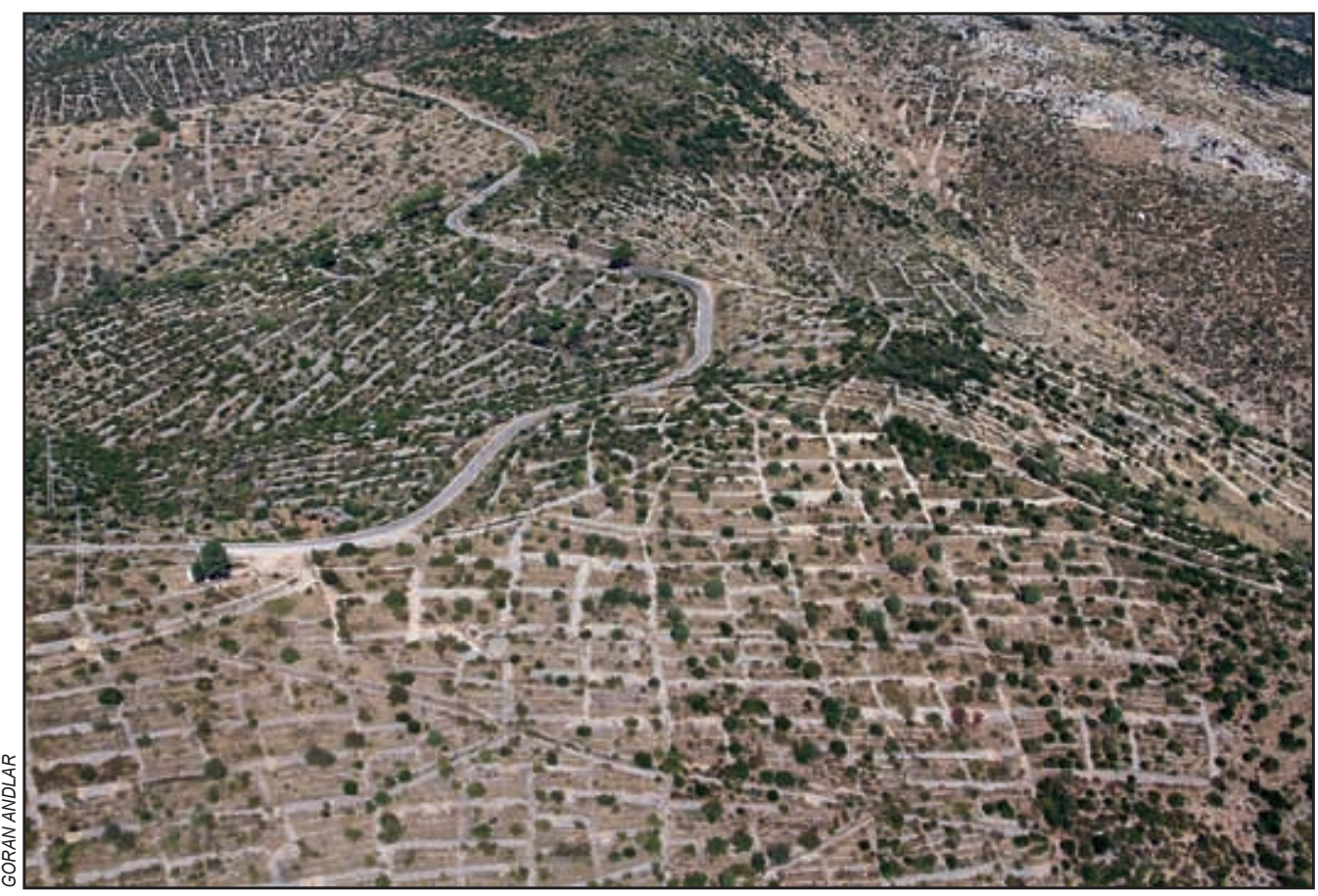

Figure 12: Typical Hvar terraces with vertical intersections.

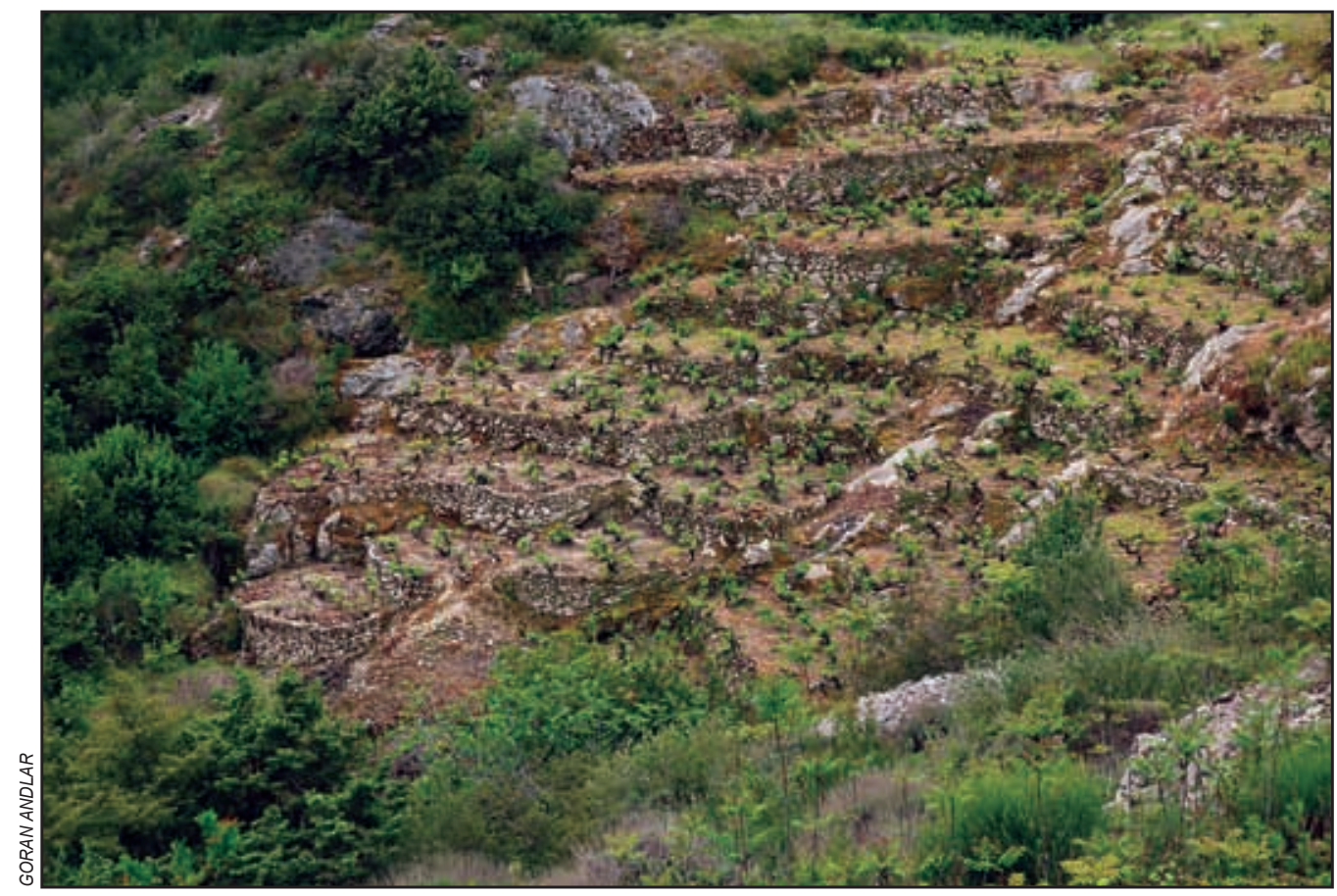

Figure 13: Vineyard pocket terraces on the island of Hvar. 


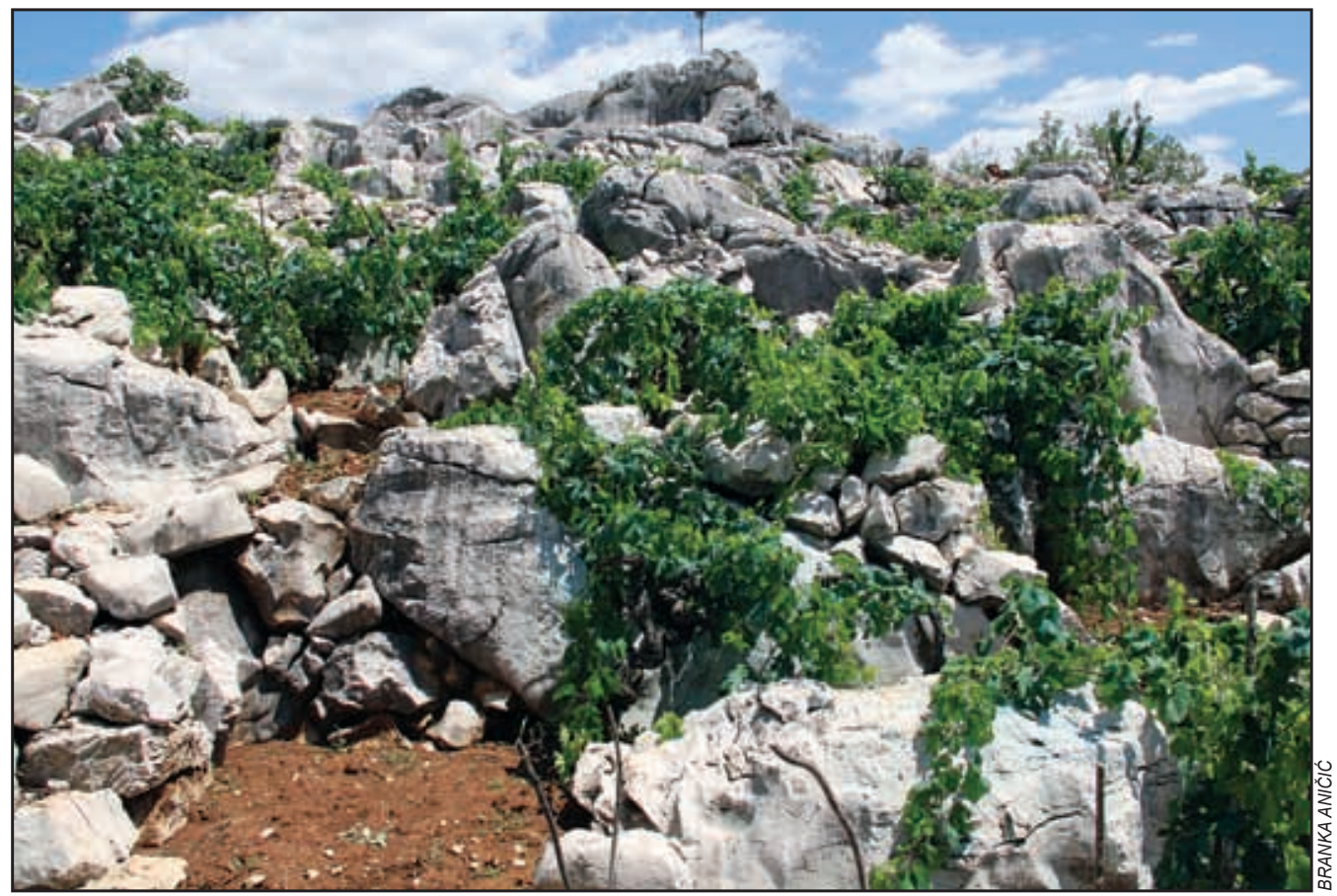

Figure 14: Vineyards on spontaneous pocket terraces in Kostanje near the Cetina River.

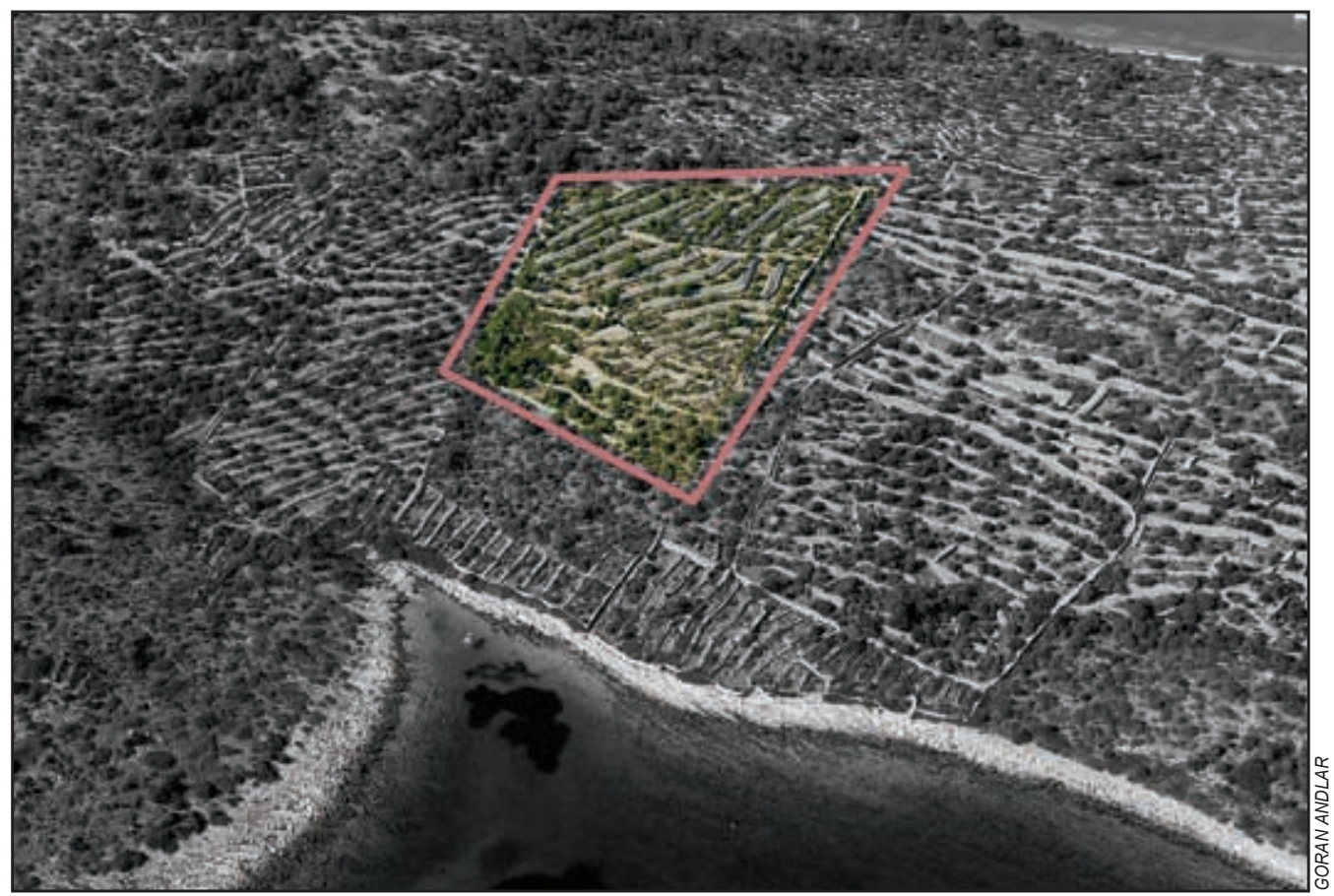

Figure 15: Off-contour terraces on the island of Kaprije. 


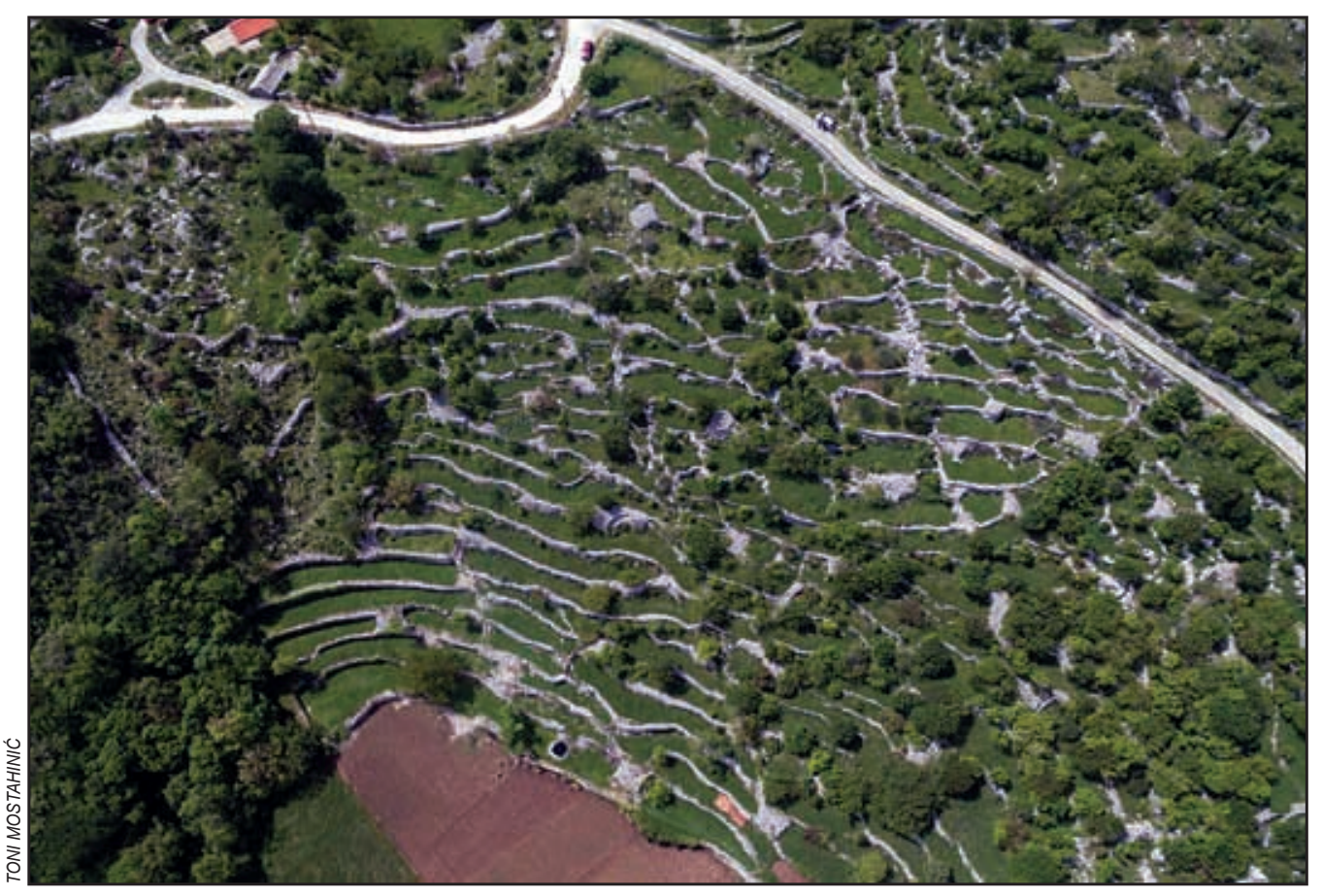

Figure 16: Irregular and pocket terraces in Duba Konavoska.

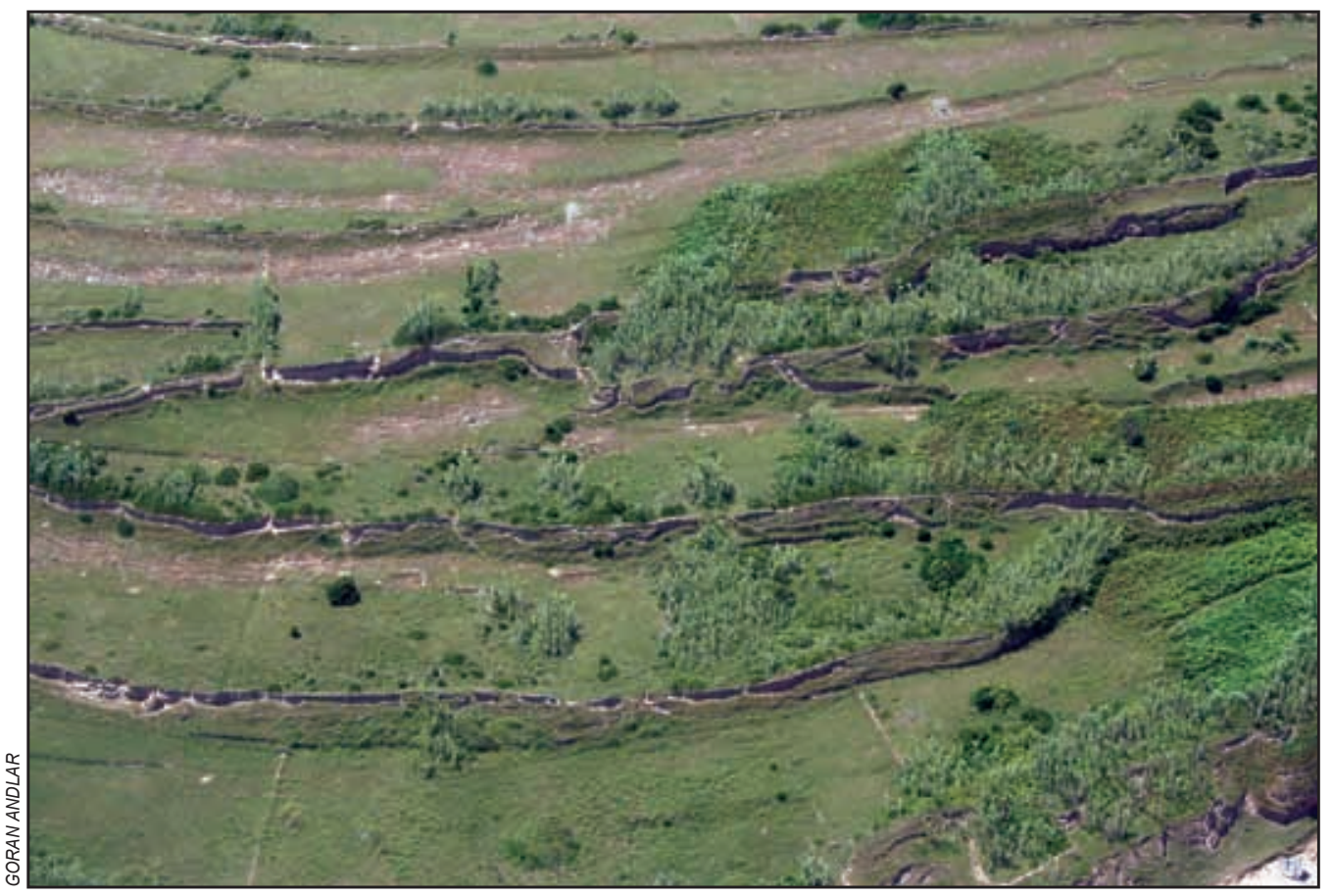

Figure 17: Abandoned reed-supported terraces on the island of Srakane. 
The layout of these terraces might be a consequence of a need for protection from the wind, but also an adaption to the direction of lithological layers. They are very rare and, as far as they are known, abandoned (e.g., small sites in the Senj-Jablanac area and on the islands of Kaprije, Baljenac, and Kakan). Gams (1987, 1991) pointed out an interesting type of the »box-like landscape« with an example of a site near Brusje, Hvar, where the terraced parcel stripes are divided by solid dry stone scarps (or sometimes simply elongated heaps of stone) perpendicular to the contours. Although they are visually impressive and similar to the off-contour terraces, these structures could not be classified as such because they are structurally a secondary feature (a boundary, path, or deposit of excess stone) in the otherwise regular horizontal terrace system.

\section{Conclusion}

The main contribution of this article is to present an original typology of terraced landscapes and to show their diversity based on the example of the Croatian Adriatic region, followed by standardized nomenclature that should facilitate further research.

We argue that standardized classifications are necessary for unifying the »language « among the various disciplines that deal with this interdisciplinary subject. They are also important for making possible comparisons between different case studies and for creating databases. We agree with the opinion that systematic quantitative techniques may expand the boundaries of historical landscape research and preservation, and that the typologies have yet to become common practice when studying historical landscapes (Kohr 2008). Using sketches (Figures 1-8) and photos (Figures 9-17), this article promotes the importance of visual presentation.

The proposed classification framework is based on landscape pattern dimensions, for which the definition of types is primarily based on structure and geomorphology, but includes other biophysical and cultural-historical circumstances. In this regard, this article is also a contribution to sociogeomorphology (Ashmore 2015).

In the proposed typology, links between the structure observed and the circumstances of its emergence can be followed up to a certain level. For every type, one can potentially know which crop it was initially intended for, what its biophysical context is, what »micro-cultural « area it belongs to, what its relation to the settlement is, and sometimes even which period or historical event it is part of. Further knowledge is needed to test the applicability of the suggested principle.

Such a generalized framework has some deficiencies. For example, certain types of terraced landscapes are sometimes connected with other types of land use.

Furthermore, the multidimensional approach of this work points to the fact that additional expertise and research is needed, especially in history and archaeology to support chronological dating and explain the socioeconomic context of the spatial structures observed.

Further research in the Croatian Adriatic region should be directed towards identifying representative sites for every terraced landscape; namely, to identify the construction materials, techniques, structures, soil characteristics, lithology, and relief that have formed the terroir (Jamšek Rupnik, Čuš and Šmuc 2016), and other associated local practices, cultures, and cultivars that may have evolved within the unique terraced landscape.

ACKNOWLEDGEMENT: The research described in this article uses findings from the research project Mediterranean Landscape as an Element of Croatian Identity, approved by the Croatian Ministry of Science, Education, and Sports. Sincere thanks to Branka Aničić, who headed this project. We also express our gratitude to Kristina Krklec for comments that greatly improved this article, and to the students at the School of Landscape Architecture (Faculty of Agriculture, University of Zagreb) for their participation in collecting valuable information through term papers, bachelor's theses, master's theses, and other activities. Thanks also to Jadran Kale, our colleagues from the association 4 GRADA DRAGODID, and all of the public contributors involved in research and development for Suhozid.hr. 


\section{References}

Acovitsióti-Hameau, A. 2008: Terraced territories: technical act and social facts. Terraced landscapes of the Alps - Atlas. Venice.

Andlar, G. 2012: Outstanding cultural landscapes of the Croatian Adriatic. Doctoral Thesis, Faculty of Agriculture, University of Zagreb. Zagreb.

Andlar, G., Aničić, B. 2017: Multi-method approaches to cultural landscape assessment in Croatia. Routledge handbook of landscape character assessment: Current approaches to characterisation and assessment. Oxford.

Aničić, B., Perica, D. 2003: Structural features of cultural landscape in the karst area. Acta Carsologica 32-1. DOI: http://dx.doi.org/10.3986/ac.v32i1.372

ARKOD, 2016. Agencija za plaćanja u poljoprivredi, ribarstvu i ruralnom razvoju. Internet: http://preglednik. arkod.hr/ARKOD-Web (10.8.2016).

Ashmore, P. 2015: Towards a sociogeomorphology of rivers. Geomorphology 251-15. DOI: http://dx.doi.org/ 10.1016/j.geomorph.2015.02.020

Asins-Velis, S. 2006: New paradigms in semi-arid Mediterranean terraced landscapes studies. Workshop: I terrazzamenti risorse del territorio. Genova.

Ažman Momirski, L., Kladnik, D. 2009: Terraced landscapes in Slovenia. Acta geographica Slovenica 49-1. DOI: http://dx.doi.org/10.3986/AGS49101

Barbarić, V. 2010: Gradina Rat kod Ložišća, otok Brač, 2007-2008. Izdanja Hrvatskog arheološkog društva 26. Bognar, A. 1999: Geomorfološka regionalizacija Hrvatske. Acta geographica Croatica 34.

Borovičkić, M. 2008: Takale: bakarsko-praputnjarski prezidi. Etnološka istraživanja 12, 13-1.

Buble, S. 2009: Agrarni krajolik otoka Visa: problematika očuvanja suhozidnog krajolika. Destinacije čežnje, lokacije samoće: uvidi u kulturu i razvojne mogućnosti hrvatskih otoka. Zagreb.

Carter, F. W. 1992: Agriculture on Hvar During the Venetian Occupation: a Study in Historical Geography. Hrvatski geografski glasnik 54-1.

Ciglič, R., Hrvatin, M., Komac, B., Perko, D. 2012: Karst as a criterion for defining areas less suitable for agriculture. Acta geographica Slovenica 52-1. DOI: http://dx.doi.org/10.3986/AGS52103

CORINE Land Cover Hrvatska, 2016. Agencija za zaštitu okoliša. Internet: http://www.azo.hr/CORINELandCover (10.8.2016).

Countryman, J. C. 2012: Agricultural terracing and landscape history at Monte Pallano, Abruzzo, Italy. Doctoral Thesis, Oberlin College. Oberlin.

Cvijić, J. 1918: Hydrographie souterraine et évolutionmorphologique du karst. Recueil des travaux de l’institut de géographie alpine 6-4.

Delort, R., Walter, F. 2002: Povijest europskog okoliša. Zagreb.

Dokoza, S. 2009: Dinamika otočnog prostora - društvena i gospodarska povijest Korčule u razvijenom srednjem vijeku. Split.

Fairclough, G. 2010: Complexity and contingency: classifying the influence of agriculture on European landscapes. European culture expressed in agricultural landscapes - perspectives from the Eucaland Project. Roma.

Filipčić, A. 1998: Climatic regionalization of Croatia according to W. Köppen for the standard period 1961-1990 in relation to the period 1931-1960. Acta geographica Croatica 33-1.

Frederick, C., Krahtopoulou, A. 2000: Deconstructing agricultural terraces: examining the influence of construction method on stratigraphy, dating and archaeological visibility. Landscape and land use in postglacial Greece. Sheffield.

Freudenreich, A. 1962: Narod gradi na ogoljenom Krasu. Savezni institut za zaštitu spomenika kulture. Zagreb, Beograd.

Gadot, Y., Davidovich, U., Avni, G., Avni, Y., Piasetzky, M., Faershtein, G., Golan, D., Porat, N. 2016: The formation of a Mediterranean terraced landscape: Mount Eitan, Judean Highlands, Israel. Journal of Archaeological Science: Reports 6.

Gams, I. 1987: A contribution to the knowledge of the pattern of walls in the Mediterranean karst. A case study on the N. island Hvar, Yugoslavia. Karst and man. Proceedings of the International symposium on human influence in karst. Ljubljana.

Gams, I. 1991: Sistemi prilagoditve primorskega dinarskega krasa na kmetijsko rabo tal. Geografski zbornik 31. 
Glavina, F. 2008: Dingač - dokumenti, tradicija, predaja. Dingač, priča o velikom hrvatskom vinu. Zagreb. Google Earth, 2016. Internet: https://www.google.com/earth (10.8.2016).

Gotthardi-Pavlovsky, B. 1972: Inscription in Register of Cultural Goods of Croatia Z-5290. Internet: http://www.min-kulture.hr/default.aspx?id=6212\&kdId=249954414 (7. 12. 2016).

Grove, A. T., Rackham, O. 2001: The nature of Mediterranean Europe: an ecological history. New Haven. Hughes, D. J. 2005: The Mediterranean: an environmental history. Santa Barbara.

Internet 1: http://www.alpter.net (10.8.2016).

Internet 2: https://ispu.mgipu.hr (10.8.2016).

Jamšek Rupnik, P., Čuš, F., Šmuc, A. 2016: Geomorphology and wine: the case of Malvasia Istriana in the Vipava Valley. Acta geographica Slovenica 56-1. DOI: http://dx.doi.org/10.3986/AGS.905

Kale, J. 2006: Kamen po kamen - krajolik. Hrvatska revija - Obnovljeni tečaj 6-2.

Kale, J. 2008: Kulturni krajolik otoka Rave. Zbornik radova »Otok Rava«. Zadar.

Kale, J. 2010: Prijedlog modela inventarizacije suhozida. Prostor 18-2.

Kale, J. 2011: Upravljanje kulturnom resursima krških krajolika. AR: Arhitektura, raziskave/Architecture, Research 3.

Kasandrić, I. 1978: Gratia - agrarni odnos na općinskoj zemlji. Prilozi povijesti otoka Hvara 5.

Kladnik, D., Ciglič, R., Geršič, M., Komac, B., Perko, D., Zorn, M. 2016a: Diversity of Terraced Landscapes in Slovenia. Annales, Series historia et sociologia 26-3. DOI: http://dx.doi.org/10.19233/ASHS.2016.38

Kladnik, D., Perko, D. (ed.), Ciglič, R. (ed.), Geršič, M. (ed.) 2016b: Terasirane pokrajine. Ljubljana.

Kladnik, D., Šmid Hribar, M., Geršič, M. 2017: Terraced landscapes as protected cultural heritage sites. Acta geographica Slovenica 57-2. DOI: http://dx.doi.org/10.3986/AGS.4628

Kohr, A. D. 2008: A terrace typology. Exploring the boundaries of historic landscape preservation, Proceeding of the $29^{\text {th }}$ Annual Conference. Clemson.

Kovačić, J. 1993: Hvarski ager u srednjem i novom vijeku. Mogućnosti 1-2.

Kraljević, R. 1994: Vinogradarski slom i demografski rasap Južne Hrvatske u osvit 20. stoljeća: vinogradarstvo Dalmacije 1850-1904: uspon, procvat, klonuće. Split.

Kulušić, S. 1999: Tipska obilježja gradnje »u suho« na kršu Hrvatskog primorja (Na primjeru kornatskih otoka). Hrvatski geografski glasnik 61-1.

Kulušić, S. 2006: Knjiga o Kornatima. Murter.

Lozić, S., Radoš, D., S Šiljeg, A., Krklec, K. 2013: Geomorfometrijske značajke s šireg područja Velog Rata i njihov utjecaj na tradicionalni kulturni krajobraz suhozida. Veli Rat, Zadar.

Marković, M. 2001: Hrvatski gradovi na starim planovima i vedutama. Zagreb.

McNeill, J. R. 2003: The mountains of Mediterranean World: An environmental history. Cambridge.

Moore, A., Menđušić, M., Smith, J., Zaninović, J., Podrug, E. 2007: Project »Early Farming in Dalmatia«: Pokrovnik 2006 (Preliminary results). Vjesnik Arheološkog muzeja u Zagrebu 40-1.

Petrić, N. 2008: Spomenici Velog Grablja. Hvar.

Pipan, P., Kokalj, Ž. 2017: Transformation of the Jeruzalem Hills cultural landscape with modern vineyard terraces. Acta geographica Slovenica 57-2. DOI: http://dx.doi.org/10.3986/AGS.4629

Price, S., Nixon, L. 2005: Ancient Greek Agricultural terraces: evidence from texts and archaeological survey. American Journal of Archaeology 109-4. DOI: http://dx.doi.org/10.3764/aja.109.4.665

Scaramellini, G. 2008: Terraced landscapes in the Alpine area: geohistorical observations and analytical perspectives. Terraced landscapes of the Alps - Atlas. Venice.

Slapšak, B., Erič, M., Mušič, B., Plevnik, D. 1998: Landscape structures survey in the Chora of Pharos. Ancient landscapes and rural structures. COST Action G2. Ljubljana.

Sluis, T. van der, Kizos, T., Pedroli, B. 2014: Landscape change in Mediterranean farmlands: impacts of land abandonment on cultivation terraces in Portofino (Italy) and Lesvos (Greece). Journal of Landscape Ecology 7-1. DOI: http://dx.doi.org/10.2478/jlecol-2014-0008

Suhozid, 2016. Internet: http://suhozid.geof.unizg.hr (7.12.2016).

Šmid Hribar, M., Geršič, M., Pipan, P., Repolusk, P., Tiran, J., Topole, M., Ciglič, R. 2017: Cultivated terraces in Slovenian landscapes. Acta geographica Slovenica 57-2. DOI: http://dx.doi.org/10.3986/AGS.4597

Titl, J. 1965: Socialnogeografski problemi na koprskem podeželju. Koper.

Trogrlić, S. 1980: Novija literatura o agrarnim odnosima u Dalmaciji u vrijeme druge austrijske uprave. Journal of the Institute of Croatian History 13-1. 
Tudor, A. 2004: Ladanjska izgradnja i formiranje agrarnog krajolika - primjeri zapadnog dijela otoka Hvara. Zbornik I. kongresa hrvatskih povjesničara umjetnosti. Zagreb.

Zaninović, M. 2002: Grčke podjele zemljišta na otocima Hvaru, Visu i Korčuli. Grčki utjecaji na istočnoj obali Jadrana. Split.

Zupančić, D. 2010: Vidoviči in kultura oblikovanja prostora. AR: Arhitektura, raziskave/Architecture, Research 1.

Žuvela-Doda, B. 2008: Preko luških mejah. Luško libro 16. 